\title{
New data on ore mineralogy and mineral chemistry of pyrite from the Pishtene ore occurrence, Western Srednogorie, Bulgaria
}

\section{Нови данни за рудните минерали и химизъм на пирита от рудопроявление Пищене, Западно Средногорие, България}

\section{Ralica Sabeva \\ Ралица Събева}

Sofia University St. Kliment Ohridski, Faculty of Geology and Geography, 1504 Sofia; E-mail: rsabeva@gea.uni-sofia.bg

\begin{abstract}
The Pishtene ore occurrence is situated north-northeast from the Pishtene paleovolcanic center in the western part of the Srednogorie zone. The occurrence is hosted by altered basaltic trachyandesites. The styles of alteration are advance argillic, argillic, sericitic and propylitic. Ore mineralization is in quartz-sericite zone and is represented by quartz-pyrite and quartz-polymetallic. The ore minerals are pyrite, chalcopyrite and sphalerite. Pyrite from quartzpolymetallic stage is with high concentrations of $\mathrm{Cu}$, Se and $\mathrm{Co}$. Au with low contents is also detected.
\end{abstract}

Keywords: Pishtene, Western Srednogorie, ore mineralogy, LA-ICP-MS of pyrite.

\section{Introduction}

The Pishtene ore occurrence is north from Pishtene (Pishtane) village which is located $50 \mathrm{~km}$ west of Sofia. The occurrence is in the western part of the Srednogorie zone, which belongs to the Late Cretaceous Apuseni-Banat-Timok-Srednogorie magmatic and metallogenic belt and hosts $\mathrm{Cu}$ - and $\mathrm{Au}-$ rich porphyry and epithermal deposits (Popov et al., 2002).

Previous studies at the area dealt with data of the geology and alteration (Velinov et al., 2007; Velev, 2017). The aim of this investigation is to add new data on the ore mineralization in quartz-sericite rocks and mineral chemistry of pyrite.

\section{Sampling and analytical techniques}

The samples are collected from the ore mineralization, hosted by sericitic alteration. Polished sections were prepared to determine the paragenetic relationships of the ore minerals.

Scanning Electron Microscopy and Energy Dispersive Spectroscopy (SEM-EDS) were done on carbon-coated polished sections with a SEM JEOL JSM 6610LV equipped with an EDS detector at the University of Belgrade, Serbia. Standards used were $\mathrm{CuFeS}_{2}(\mathrm{Cu}, \mathrm{Fe}, \mathrm{S})$, metallic $\mathrm{Mn}(\mathrm{Mn}), \mathrm{ZnS}$ (Zn), InAs (As), metallic Se (Se), CdS (Cd), metallic $\mathrm{Ag}(\mathrm{Ag}), \mathrm{Ag}_{2} \mathrm{Te}(\mathrm{Ag}, \mathrm{Te}), \mathrm{InSb}(\mathrm{Sb})$, metallic Co $(\mathrm{Co})$, metallic $\mathrm{Ni}(\mathrm{Ni})$, metallic $\mathrm{Bi}(\mathrm{Bi}), \mathrm{PbS}(\mathrm{Pb})$, metallic $\mathrm{Au}(\mathrm{Au})$.

Trace element concentrations in pyrite were measured by LA-ICP-MS on polished sections at the Geological Institute (Bulgarian Academy of Sciences). A total of 54 analyses were performed on PerkinElmer ELAN DRC-e ICP-MS equipped with a New Wave UP193-FX excimer laser ablation system. NIST SRM 610 glass and MASS 1 was used as external standard and stoichiometric Fe as internal. The laser system was operated at constant $10 \mathrm{~Hz}$ pulse rate; laser energy was $10.10 \mathrm{~J} / \mathrm{cm}^{2}$ on SRM 610 glass and $1.90-3.06 \mathrm{~J} / \mathrm{cm}^{2}$ on sample. Spot size was $50 \mu \mathrm{m}$ in diameter. Acquisition dwell time for all masses was set to $0.01 \mathrm{~s}$. Data reduction was undertaken using SILLS ver. 1.1.0 software (Guillong et al., 2008).

\section{Geology and hydrothermal alteration}

The Pishtene ore occurrence is in the western part of the Srednogorie zone and is situated N-NE from 
the Pishtene paleovolcanic center. Pishtene paleovolcano is with Coniacian-Campanian age and corresponds to formation of the Lower volcanogenicsedimentary unit (Bairaktarov, 1989; Dabovski et al., 2009). The volcanic edifice is composed predominantly by volcanic plugs (necks), lava flows, volcaniclastic rocks (both pyroclastic and epiclastic) and later dykes. According to classifications, rocks are defined as basaltic trachyandesites (mugearites) (Velev, 2017).

Hydrothermal alteration occurs N-NE from the paleovolcanic center and consists of advance argillic (Ivanchova Glava hill), argillic, sericitic and propylitic rocks. The mineral assemblages of advanced argillic alteration zone are quartz-kaolinite and quartzkaolinite-alunite, while vuggy quartz zone is scarce (Sabeva, Georgieva, 2019). Velinov et al. (2007) report also illite, pyrophillite and rare diaspore. Argillic alteration zone is rare and dominated by clay minerals. Sericitic zone is structure-controlled with thickness 4-5 m, NW-striking and hosts the ore mineralization. The alteration minerals are fine-grained quartz, sericite and subhedral to anhedral pyrite. The original rock texture is preserved and formed by plagioclase phenocrysts, which are partly to completely altered to sericite. Propylites occur in the outer parts of the occurrence and consist of chlorite-carbonateepidote assemblage with late laumontite-albite-montmorillonite-chabazite and laumontite-stilbite veins (Sabeva, Georgieva, 2019).

\section{Ore mineralogy and mineral chemistry}

Ore mineralization is hosted by the sericitic alteration. Main ore mineral is pyrite and together with other sulfides form nests and disseminations among quartz-sericitic groundmass. On the basis of mineral assemblage mineralization can be referred to two ore stages - quartz-pyrite and quartz-polymetallic. The gangue minerals are quartz and barite, proven by SEM-EDS analyses.

Pyrite is the most abundant in Pishtene ore occurrence and it is deposited in two ore stage. Pyrite I from the quartz-pyrite stage occurs as semi- to anhedral crystals and fine- to medium-grained aggregates in quartz. The size of the single grains varies from about 5 to $250 \mu \mathrm{m}$, mainly about $50-100 \mu \mathrm{m}$. Atoll-like and skeletal textures are typical for the pyrite from this stage. Pyrite II from the quartz-polymetallic stage is deposited together with sphalerite and chalcopyrite. It occurs as euhedral to semihedral crystals with size predominantly about $200 \mu \mathrm{m}$ and forms nests and veinlets. Very often pyrite is full of pores and microfractures in which microinclusions of other minerals can be observed.

Pyrite II is analyzed with SEM-EDS and LAICP-MS. SEM-EDS results confirm the presence of $\mathrm{Cu}$ (from 0.43 to $0.81 \mathrm{wt} \%$ ). Preliminary data from LA-ICP-MS are reported by Sabeva and Georgieva (2019). This study adds more data on mineral chemistry of pyrite. High concentration of $\mathrm{Cu}$ (from 3.02 to $12649.22 \mathrm{ppm}$, average $1941 \mathrm{ppm}$ ), Se (from 13.76 to $372.93 \mathrm{ppm}$, average $123.53 \mathrm{ppm}$ ) and Co (0.30 to $940.28 \mathrm{ppm}$, average $84.62 \mathrm{ppm})$ were detected. Cobalt, together with Ni (average 56.30 $\mathrm{ppm}$ ) substitute for $\mathrm{Fe}^{2+}$ in pyrite lattice. The $\mathrm{Co} / \mathrm{Ni}$ ratio is an important indicator of the environment of pyrite deposition. The $\mathrm{Co} / \mathrm{Ni}$ ratio in pyrite II from the Pishtene occurrence is highly variable but with average 1.50 i.e. $1<\mathrm{Co} / \mathrm{Ni}<5$, which corresponds to pyrite with hydrothermal origin (Bralia et al., 1979; Raymond, 1996). Selene substitutes for $\mathrm{S}_{2}^{2-}$. According to Huston et al. (1995), Se-containing pyrite associates with $\mathrm{Cu}$ and is typical for copper
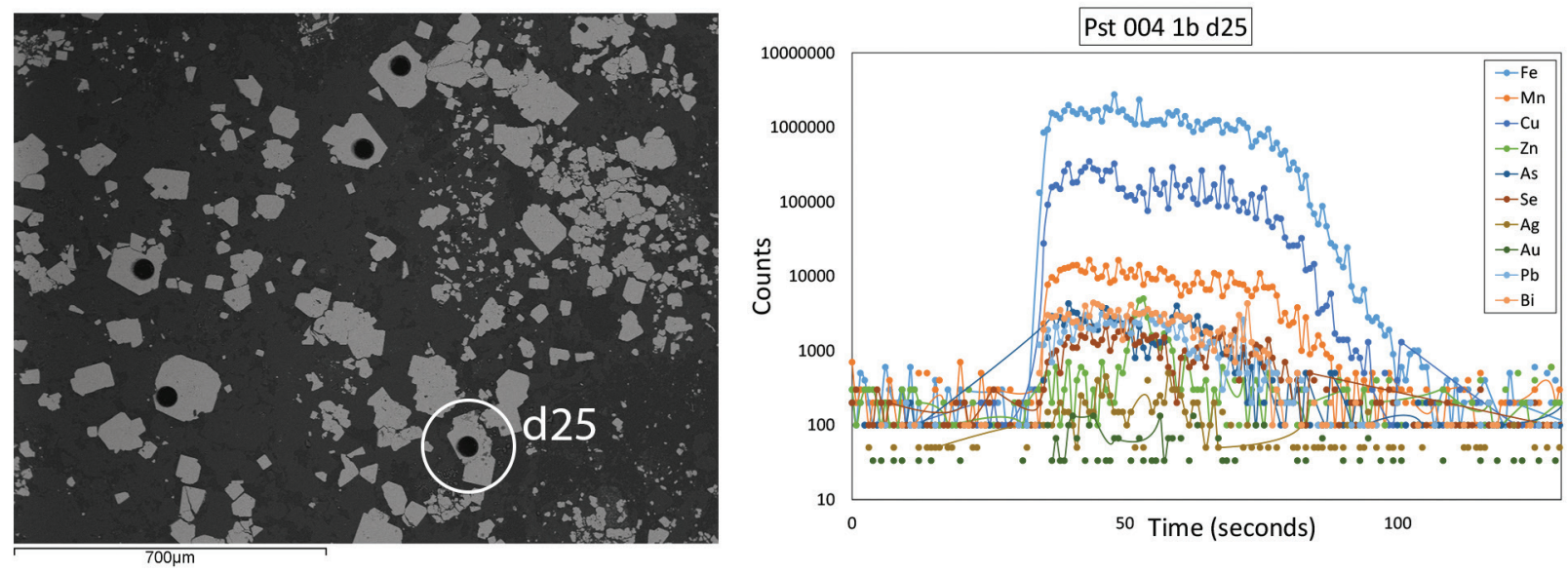

Fig. 1. Depth spectra of pyrite: left, SEM-EDS image of pyrite II grains from the Pishtene ore occurrence, analyzed spot d25 is shown; right, representative LA-ICP-MS spectra for selected elements in spot d25 with concentrations (in ppm): $\mathrm{Cu}, 5357.55$; Se, 87.07; Mn, 46.99; As, 42.85; Zn, 29.09; Pb, 7.90; Bi, 6.94; Ag, 1.06; Au, 0.33 
deposits. Copper is the most abundant trace element in pyrite in Pishtene. Positive correlation with $\mathrm{Fe}$ and As (up to $91.15 \mathrm{ppm}$ ) and the smooth ablation profiles in some depth spectra indicate that part of the $\mathrm{Cu}$ is structurally-bond in pyrite (Abraitis et al., 2004). Manganese, $\mathrm{Zn}$ and $\mathrm{Pb}$ are also detected and probably represented as micro-inclusions of minerals, deposited in pores and microfractures. Gold contents are low (up to $0.37 \mathrm{ppm}$ ) and obtained for single grains. It shows both smooth profiles and spikes in the depth spectra which prove his presence as structurally-bond and also as micro-inclusions (Fig. 1).

Chalcopyrite is deposited in the quartz-pollymetallic stage. It occurs as anhedral grains with size from $<10$ to $30 \mu \mathrm{m}$ in pores and microfractures in quartz and as inclusions in sphalerite as "chalcopyrite disease".

Sphalerite is rarer than chalcopyrite. It can be observed as small grains with size up to $50 \mu \mathrm{m}$ amongst the aggregates of pyrite II. Irregularly distributed small chalcopyrite inclusions with spherical forms, known as "chalcopyrite disease" occur in sphalerite.

\section{Conclusions}

According to the geological settings, alteration style of the host rocks, main textures and to new data of the mineral assemblages and composition of pyrite the Pishtene ore occurrence can be referred as epithermal sulfidation type and with probable high sulfidation mineralization. Copper is dominant and $\mathrm{Au}$ contents are low but future studies will add more data and clarify the prospects of the ore occurrence.

Acknowledgments: This work was financially supported by the DM 04/2 grant from 13.12.2016 of the National Science Fund Bulgaria.

\section{References}

Abraitis, P. K., R. A. D. Pattrick, D. J. Vaughan. 2004. Variations in the compositional, textural and electrical properties of natural pyrite: a review. - Int. J. Miner. Process., 74, 41-59; https://doi.org/10.1016/j.minpro.2003.09.002.

Bairaktarov, I. 1989. Late Cretaceous Metallogeny of Western Srednogorie and Plana Mountain. PhD Thesis, Sofia, Research Institute for Mineral Resources, 197 p. (in Bulgarian).

Bralia, A., G. Sabatini, F. Troja. 1979. A revaluation of the $\mathrm{Co} /$ Ni ratio in pyrite as geochemical tool in ore genesis problems. Evidences from southern Tuscany pyritic deposits. - Mineral. Deposita, 14, 353-374; https://doi.org/10.1007/ BF00206365.

Dabovski, C., B. Kamenov, D. Sinnyovsky, E. Vasilev, E. Dimitrova, I. Bairaktarov. 2009. Upper Cretaceous geology. - In: Zagorchev, I., Dabovski, C., Nikolov, T. (Eds.). Mesozoic Geology of Bulgaria. Sofia, Prof. Marin Drinov Academic Publishing House, 305-611.

Guillong, M., D. L. Meier, M. M. Allan, C. A. Heinrich, B. W. D. Yardley. 2008. Appendix A6: SILLS: A MATLABbased program for the reduction of laser ablation ICP-MS data of homogeneous materials and inclusions. - In: Sylvester, P. (Ed.). Laser Ablation ICP-MS in the Earth Sciences: Current Practices and Outstanding Issues. Mineralogical Association of Canada Short Course 40, Vancouver, B. C., 328-333.

Huston, D. L., S. H. Sie, G. F. Suter, D. R. Cooke, R. A. Both. 1995. Trace elements in sulfide minerals from Eastern Australian volcanic-hosted massive sulfide deposits: Part I. Proton microprobe analyses of pyrite, chalcopyrite, and sphalerite. Part II. Selenium levels in pyrite: Comparison with $\delta^{34} \mathrm{~S}$ values and implications for the source of sulfur in volcanogenic hydrothermal systems. - Econom. Geol., 90, 1167-1196; https://doi.org/10.2113/gsecongeo.90.5.1167.

Popov, P., T. Berza, A. Grubic, I. Dimitru. 2002. Late Cretaceous Apuseni-Banat-Timok-Srednogorie (ABTS) Magmatic and Metallogenic Belt in the Carpathian-Balkan Orogen. - Geologica Balc., 32, 2-4, 145-163; https://doi. org/10.1007/s00126-009-0239-1.

Raymond, O. L. 1996. Pyrite composition and ore genesis in the Prince Lyell copper deposit, Mt Lyell mineral field, western Tasmania, Australia. - Ore Geol. Rev., 10, 231250; https://doi.org/10.1016/0169-1368(95)00025-9.

Sabeva, R., H. Georgieva. 2019. LA-ICP-MS of pyrite from sericitic alteration: Zlatousha and Pishtene ore occurrences, Western Srednogorie, Bulgaria. - Goldschmidt Abstracts 2019, 2923.

Velev, S. 2017. Petrology of Volcanic Complexes from Western Srednogorie. PhD Thesis, Sofia University, 200 p. (in Bulgarian).

Velinov, I., A. Kunov, N. Velinova. 2007. The Metasomatic Secondary Quartzite Formation in Bulgaria. Sofia, Prof. Marin Drinov Academic Publishing House, 198 p. 